\title{
Identification the effect of Behaviour on Traffic Accident Level with Stuctural Equation Modelling (SEM)
} Case Study of Motorcyclists in Surabaya City

\author{
Arfa’ Najmy \\ Manajemen Industri \\ ITS \\ Surabaya, Jawa Timur, Indonesia
}

Prof. Dr. Ir. Udisubakti Ciptomulyono, Meng.Sc. Manajemen Industri

ITS

Surabaya, Jawa Timur, Indonesia

\author{
Ratna Sari Dewi, S.T., M.T. Ph.D \\ Manajemen Industri \\ ITS \\ Surabaya, Jawa Timur, Indonesia
}

\begin{abstract}
Accidents in traffic are affected by low levels of consciousness of safety. This safety level is the behavior of motorcyclists. Behavior indicators are knowledge of traffic signs, discipline attitude, and vehicle maintenance. this study aims to find out how much influence the knowledge about traffic signs, disciplinary attitude, and vehicle maintenance to motorcycle rider behavior in traffic accidents. The method of Structural Equation Modeling (SEM) with Confirmatory Factor Analysis (CFA) through Analysis Moment of Structure Analysis (AMOS) version 22 and questionnaire required amounted to 242 respondents used to identify indicators in this study. It is expected in this research to be able to know how big influence of knowledge about traffic sign, disciplinary attitude of rider, and vehicle maintenance to behavior at traffic accident in Surabaya city. The result showed that the variable knowledge and discipline attitude, have a positive and significant influence, but vehicle maintenance variable have negative and insignificant effect on the decrease of traffic accident level in surabaya city.
\end{abstract}

Keywords- Knowledge; Discipline Attitude; Vehicle Maintenance; Taffic Accident; Structur Equation Modelling.

\section{INTRODUCTION}

One of the world's most concerned aspect within the sphere of public transportation is a traffic accident. This is indicated by WHO in 2011 during the launch of Decade of Action for Road Safety 2011-2020. With an invitation to stop and reverse the trend of high death rates caused by road accidents, Indonesia is also one of the countries under UN auspices to improve national safety with the 2011-2035 National Road Safety Plan (RUNK) 2011-2035.

The cause of traffic accidents, according to the police, is divided into 4: natural factors (a), road factors (b), vehicle factors (c), and driver factors (d). Without taking in account trend, Figure 1.1 shows that the driver is still the highest factor in the cause of the accident. It can also be seen that there is an increase in accident rates ranging from 47\% from 2014 to 2017.

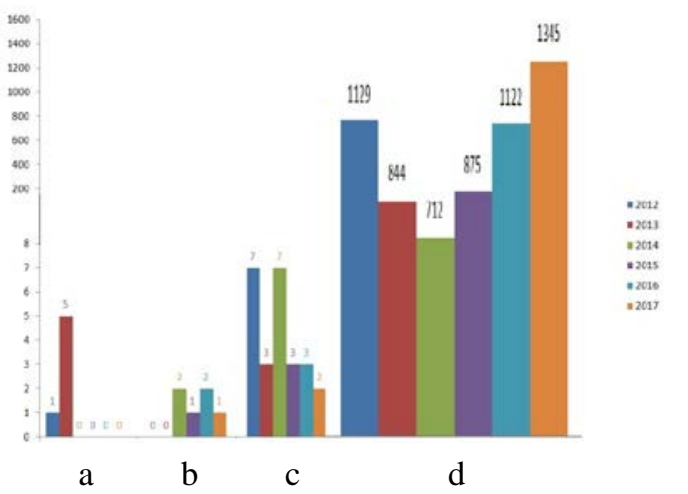

Figure 1.1 Factors Cause Accident POLRESTABES Surabaya 2017 (Source: POLDA JATIM)

This research tries to identify the influence of motorist behavior on traffic accident level. The results of this study can be used as consideration information / material for the authority to create policies, programs and appropriate strategies to reduce the number of accidents. This study was adopted from Wesli ${ }^{[1]}$ as well as the differences from the indicators that a certain behavior influences including knowledge of traffic rules, disciplinary attitude, and car care in relation to traffic accidents in Surabaya city. The method used is structural equation modeling (SEM) with 242 respondents acquired using questionnaires, the data then used to obtain confirmatory factor analysis (CFA) and then processed using the software, analysis moment of structure (AMOS) version 22. By using SEM, the indicator that influence the behavior in traffic it can then be more precisely explained, what it influences and how much influence on the accident this is facilitated by path analysis. 


\section{MATERIAL AND METHODS}

This prospective comparative study was carried out using motorcyclist as a cause of accident from POLRESTABES at Surabaya city. The researchers are Arfa' najmy, Udisubakti ciptomulyono, and Ratna sari dewi, conducted from November 2017 to July 2018. A total of 242 respondent is obtained with the date collection performed in license corners at Surabaya city.

\section{A. Behaviour}

An accident had a lot of factors that causes it, it can happen because of humans, machinery / vehicles, roads, and the environment. Human factors are influenced by drivers, passengers and road use; while vehicle related factors influenced by non-motorized vehicles, motor vehicles. Street factors are influenced by the state of the road, it can be influenced by the weather and geography. Driving is part of the driver - road system - vehicle ${ }^{[2]}$ :

\section{- $\quad$ Driver (X1)}

High degree of compliance with positive written law, also determined by the level of awareness of motorists, this will be based on the following factors ${ }^{[1]}$ :

1. Knowledge of the rules

2. Knowledge of regulatory contents

3. Attitude to the rules

4. Regulated compliances

\section{- $\quad$ Road System (X2)}

According to the traffic law Act no. 22 Year 2009, anyone who uses the road is obliged to behave in an orderly manner and prohibited to create any obstacles, endangering the security and safety of traffic and road transport, or cause road damage. Comply with the boundary of road classes, road signs and signs, traffic signaling equipment, work time and rest periods, traffic movements, stops and parking, technical requirements and motor vehicle worthiness, motor vehicle usage, warning with sounds and rays, maximum / minimum speed, person transport procedures, coupling and other vehicle attachments. This can be set with signs 3$]$ :
1. Warning signs
2. Command signs
3. Signs banning
4. Guide signs.

\section{- $\quad$ Vehicle (X3)}

The road transport system is a series of interactions between parts of vehicle, road, and driver. Nowhere is that interaction more evident than in the behavior of the motorcyclist. Things to watch out for a vehicle ${ }^{[4]}$ :
1. Service periodically
2. Turn on the headlight
3. Check the brake condition
4. Check the tire condition
5. Check the muffler condition

\section{- $\quad$ Traffic Accident (Y)}

According to Regulation No. 22 of 2009[5], traffic accidents are unexpected events involving vehicles with or without other road users, resulting in human casualties (minor injuries, serious injuries, and death) and property losses. Then the law also explains that the role of transportation aims to realize traffic and road transport safely, quickly, smoothly, orderly and regularly, comfortable and efficient, able to integrate other modes of transportation, reach all corners of the mainland, and to support equity, growth and stability as drivers, supporting the development of the masses at affordable costs. In this study traffic accident includes ${ }^{[1]}$ :

1. accident rate

2. type of accident

3. time of accident

4. accidental fatalities

\section{B. Structural Equation Modelling}

Structural Equation Modeling is a set of statistical techniques that allows testing of a relatively complex set of relationships simultaneously[6]. The relationship is built between one or more dependent variables with one or more independent variables. The ultimate goal of SEM, in principle, is to obtain a structural model. When the parameter estimation is based on the input data of the covariance matrix, the SEM produces a structure useful for prediction or proof of the model. In this case SEM is equivalent to regression analysis. Whereas if input is a correlation matrix then SEM is useful to check the magnitude of direct or indirect influence or influence of total exogenous variable (independent variable) to Endogen variable (dependent variable). It can also be used to determine the dominant influential variable so that there is a call it the dominant factor analysis.

CFA is part of the Structural Equation Modeling method. CFA is not a method for finding factor structure, but rather to confirm the existence of a specific factor structure. One of the advantages of the Confirmatory Factor Analysis is its degree of flexibility when applied in a complex hypothetical model. The most widely used Confirmatory Factor Analysis Technique is Maximum Likelihood which can determine the optimal value of loading factor in Confirmatory Factor Analysis.

\section{Procedure methodology}

In this study, indicators based on previous research wesli $^{[1]}$ were given to motorcyclists. Researchers went to the license corner and surrounding areas to meet with respondents. With a total of 242 respondents who already gave their opinion about the behavioral indicators of the decrease in traffic accident rate. Indicators of this behavior include; knowledge, discipline and car care. After obtaining it, it is followed by establishing a confirmatory factor analysis (CFA) model. If all respondents have entered into the driver data then CFA can be done. If the value of the indicator on the CFA is not significant it is then abolished. After completion, the all of the significant CFA indicator will be applied to the final structure model, afterwards a significant indicator in the structural model followed by testing the structure model to determine whether it is all significant. Is the optimization and 
modification of the model still required? After the fit model can then be analyzed for relationship between latent variables.

\section{Statistical analysis}

Rider's knowledge and rider's discipline attitude seen on the model has been tested significantly, with the knowledge of the rider 2 indicators and the disciplinary attitude of the rider 11 indicators. When vehicle maintenance has been tested insignificant with 5 indicators. Chi-square, RMSEA, and RMR after testing have decreased while GFI and AGFI experienced an increase near the fit model.

\section{RESULT AND DISCUSSION}

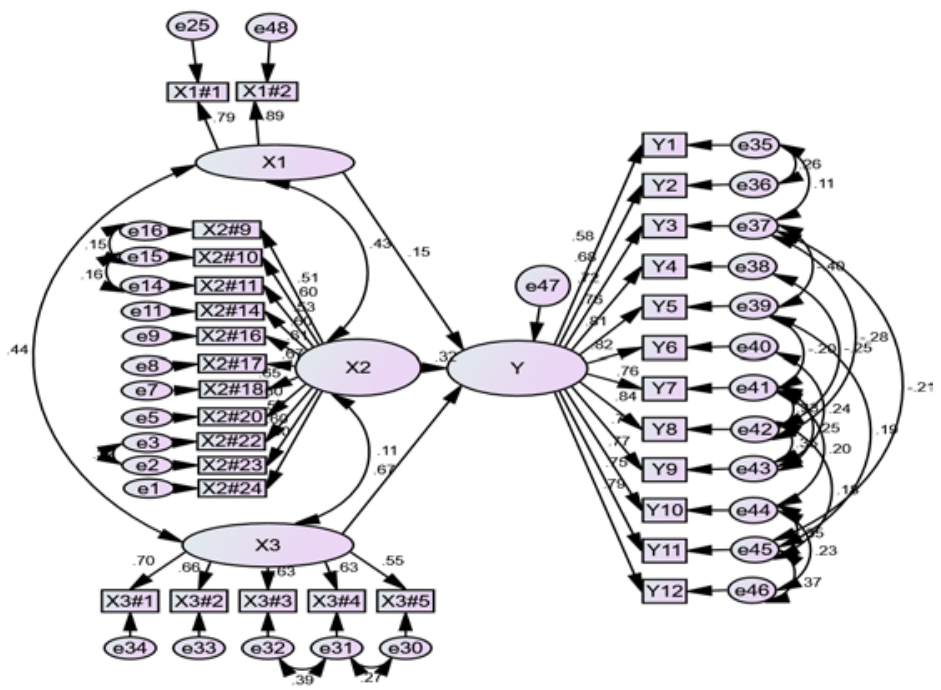

Figure 1.2 Model of The Final Structure

Table no 1: Comparison of Model Output Results before and after modification

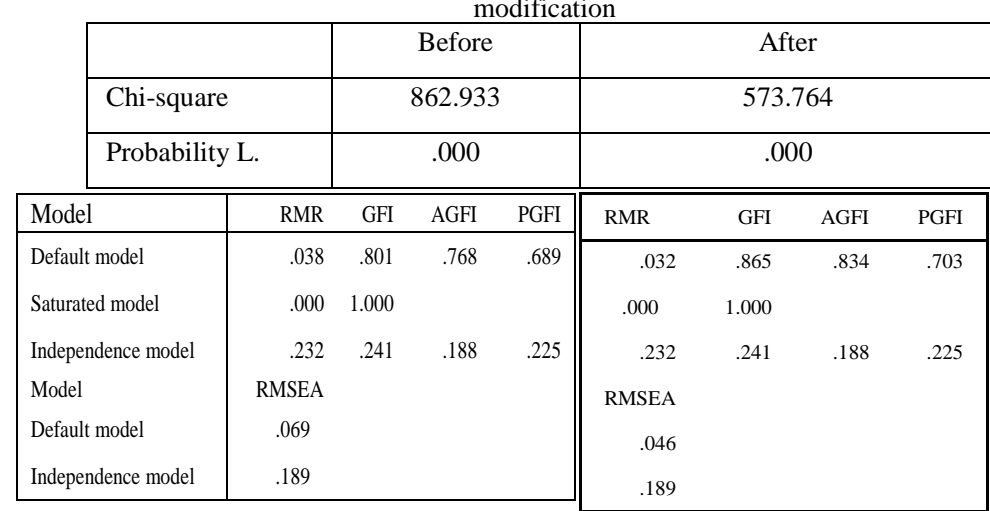

Table no. 1 shows comparison of model output results before and after modification to get fit model. Chi square shows before modification 862.933 and 573.764 after modification. GFI model from 0.801 increased up to 0.865 and AGFI increased up too, from 0.768 to 0.834 . RMR score from 0.038 into 0.032 and RMSEA from 0.069 into 0.46 . The result shows structure model forms the fit model.
Table no 2: P- Value Structure Model

\begin{tabular}{|c|c|c|c|c|c|c|c|c|c|c|c|c|c|}
\hline & & Estimate & S.E. & C.R. & $\mathrm{P}$ & Labe & & & Estimate & S.E. & C.R. & $\mathrm{P}$ & Label \\
\hline $\mathrm{Y}$ & $<-X_{1}$ & .070 & .035 & 2.001 & .045 & & $\mathrm{X} 3 \| \mathbf{2}$ & $<\ldots+x 3$ & .842 & .123 & 6.864 & **** & \\
\hline Y & $<x x_{3}$ & .105 & .103 & 1.016 & .310 & & $\mathrm{X} 3 \# 1$ & $<\ldots \times 3$ & 1.089 & .154 & 7.072 & *** & \\
\hline $\mathrm{Y}$ & $<-\mathrm{X} 2$ & .352 & .126 & 2.790 & .005 & & Y1 & $<-y$ & 1.000 & & & & \\
\hline $\mathrm{X} 2 \mathrm{H} 24$ & 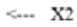 & 1.000 & & & & & Y2 & $<-y$ & 1.345 & .138 & 9.748 & ... & \\
\hline $\mathrm{X} 2 * 23$ & $<\ldots x 2$ & 1.054 & .163 & 6.466 & *** & & Y3 & $<\ldots \mathrm{Y}$ & 1.307 & .141 & 9.285 & ** & \\
\hline $\mathrm{X} 2 * 22$ & $<\ldots x 2$ & 1.007 & .161 & 6.254 & $* *$ & & Y4 & $<\ldots . . \mathrm{Y}$ & 1.463 & .160 & 9.124 & *.** & \\
\hline$x 2 \approx 20$ & 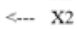 & 1.012 & .157 & 6.458 & $* * *$ & & YS & <... $\mathrm{Y}$ & 1.827 & .192 & 9.491 & ...* & \\
\hline $\mathrm{X} 2 \# 18$ & $<-x 2$ & 1.134 & .168 & 6.758 & $* * *$ & & Y6 & 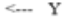 & 1.775 & 185 & 9.585 & ... & \\
\hline $\mathrm{X} 2 \# 17$ & $<\ldots \times 2$ & 1.089 & .159 & 6.841 & $\cdots$ & & Y7 & $<\ldots \mathrm{Y}$ & 1.512 & .166 & 9.089 & *.*. & \\
\hline $\mathrm{X} 2 * 16$ & $\ldots \mathrm{x} 2$ & 1.100 & .169 & 6.506 & $* * *$ & & Y8 & $<\ldots . \quad \mathrm{Y}$ & 1.747 & 181 & 9.633 & ... & \\
\hline $\mathrm{X} 2 \# 14$ & $<\ldots \times 2$ & 1.024 & .157 & 6.503 & $\ldots$ & & Y9 & $<\ldots y$ & 1.658 & 列 177 & 9.360 & ... & \\
\hline X2iil1 & 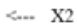 & 1.071 & .178 & 6.026 & ... & & Y10 & $<-\ldots \mathrm{Y}$ & 1.635 & . 177 & 9.241 & *** & \\
\hline $\mathrm{X} 2 \approx 10$ & $<\ldots X 2$ & 1.187 & 184 & 6.461 & & & Y11 & <... $\mathrm{Y}$ & 1.602 & . 178 & 8.993 & *.* & \\
\hline $\mathrm{X} 2 \# 9$ & $<\ldots x 2$ & .853 & .146 & $\begin{array}{l}5.480 \\
5.860\end{array}$ & *.* & & $\mathrm{Y} 12$ & $<\ldots \mathrm{Y}$ & 1.664 & . 178 & 9.354 & ...* & \\
\hline X3" & $<\mathrm{X} 3$ & 1000 & & & 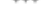 & & $\mathrm{X} 1 \# 1$ & $<\ldots x 1$ & .519 & .029 & 18.054 & *.* & ลаม \\
\hline $\mathrm{X} 3 \# 4$ & $<\ldots \times 3$ & & & 7806 & & & $\mathrm{X} 1=1 \mathrm{i} 2$ & $<x$ X1 & 519 & .029 & 18.054 & & ลаม \\
\hline K3\#3 & $<\ldots \times 3$ & 910 & .137 & 6.666 & . & & & & & & & & \\
\hline
\end{tabular}

Table no. 2 shows $\mathrm{P}$ - an almost thorough significant value according to AMOS 22. The structure model had Pvalue more than significant according AMOS 22. AMOS has a sensitive P- value of 0,001 . Structure model shows P- Value $\mathrm{X} 1, \mathrm{X} 2$, and $\mathrm{X} 3$ to $\mathrm{Y}$ more than 0,001. Actual to be considered the significant the value needs to be more than 0,005. Final only X3 to Y not significant.

Table no 2 shows 2 indicators with "AAA" label, this is based on indicator X1 \# 2 which has a value of more than 1 that makes the model error. Solution to the error is similar with the HEYWOOD CASE. The regression value on the parameter is replaced by the same label for all indicators in the same latent variable, and the value of variance in the parameter is 1 .

Table no 3: Standardize Regression Weights

\begin{tabular}{|c|c|c|c|c|c|c|c|}
\hline & & & Estimate & & & & Estimate \\
\hline $\mathrm{Y}$ & $<---$ & $\mathrm{X} 1$ & .154 & $\mathrm{X} 3 \# 2$ & $<---$ & $\mathrm{X} 3$ & .661 \\
\hline $\mathrm{Y}$ & $<---$ & $\mathrm{X} 3$ & .112 & $\mathrm{X} 3 \# 1$ & $<---$ & $\mathrm{X} 3$ & .704 \\
\hline $\mathrm{Y}$ & $<---$ & $\mathrm{X} 2$ & .315 & Y1 & $<---$ & $\mathrm{Y}$ & .582 \\
\hline $\mathrm{X} 2 \# 24$ & $<---$ & $\mathrm{X} 2$ & .496 & Y2 & $<---$ & $\mathrm{Y}$ & .675 \\
\hline $\mathrm{X} 2 \# 23$ & $<---$ & $\mathrm{X} 2$ & .600 & Y3 & $<---$ & $\mathrm{Y}$ & .725 \\
\hline $\mathrm{X} 2 \# 22$ & $<---$ & $\mathrm{X} 2$ & .567 & Y4 & $<---$ & $\mathrm{Y}$ & .761 \\
\hline $\mathrm{X} 2 \# 20$ & $<---$ & $\mathrm{X} 2$ & .597 & Y5 & $<---$ & $\mathrm{Y}$ & .813 \\
\hline $\mathrm{X} 2 \# 18$ & $<---$ & $\mathrm{X} 2$ & .650 & Y6 & $<---$ & $\mathrm{Y}$ & .821 \\
\hline $\mathrm{X} 2 \# 17$ & $<---$ & $\mathrm{X} 2$ & .666 & Y7 & $<---$ & $\mathrm{Y}$ & .764 \\
\hline $\mathrm{X} 2 \# 16$ & $<---$ & $\mathrm{X} 2$ & .605 & Y8 & $<---$ & $\mathrm{Y}$ & .839 \\
\hline $\mathrm{X} 2 \# 14$ & $<---$ & $\mathrm{X} 2$ & .605 & Y9 & $<---$ & $\mathrm{Y}$ & .794 \\
\hline $\mathrm{X} 2 \# 11$ & $<---$ & $\mathrm{X} 2$ & .533 & Y10 & $<---$ & $\mathrm{Y}$ & .774 \\
\hline $\mathrm{X} 2 \# 10$ & $<---$ & $\mathrm{X} 2$ & .601 & Y11 & $<---$ & $\mathrm{Y}$ & .751 \\
\hline $\mathrm{X} 2 \# 9$ & $<---$ & $\mathrm{X} 2$ & .510 & Y12 & $<---$ & $\mathrm{Y}$ & .789 \\
\hline $\mathrm{X} 3 \# 5$ & $<---$ & $\mathrm{X} 3$ & .546 & $\mathrm{X} 1 \# 1$ & $<---$ & $\mathrm{X} 1$ & .793 \\
\hline $\mathrm{X} 3 \# 4$ & $<---$ & $\mathrm{X} 3$ & .628 & $\mathrm{X} 1 \# 2$ & $<---$ & $\mathrm{X} 1$ & .894 \\
\hline $\mathrm{X} 3 \# 3$ & $<---$ & $\mathrm{X} 3$ & .628 & & & & \\
\hline
\end{tabular}

Table no 3 shows a score of standardized regression regarding the magnitude of structure model. X1, X2, and X3 in regards to the decrease of accident rate need optimization. The indicator of latent variable is acceptable exceptions are score X2 for X2\#4 0,496 which needs optimization to reach a score value of more than 0,5 . In actuality all indicator need optimization for road safety. 
Table no 4: Hypothesis Test Result

\begin{tabular}{|l|c|c|c|c|c|}
\hline \multicolumn{1}{|c|}{ Conrelation } & Standardize R. W. & Covariance & P-Value & Information & hypothesis \\
\hline $\begin{array}{l}\text { Knowledge has a positive influence } \\
\text { on the decrease in traffic accident } \\
\text { rate }\end{array}$ & 0.154 & - & 0.045 & Significant & $\begin{array}{c}\mathrm{H} 1 \\
\text { Accept }\end{array}$ \\
\hline $\begin{array}{l}\text { Attitudes have a positive influence } \\
\text { on the dectease in traffic accidents }\end{array}$ & 0.315 & - & 0.005 & Significant & $\begin{array}{c}\mathrm{H} 2 \\
\text { Accept }\end{array}$ \\
\hline $\begin{array}{l}\text { Vehicle maintenance has a positive } \\
\text { effect on the dectease in traffic } \\
\text { accident rate }\end{array}$ & 0.112 & - & 0.31 & Insignificicant & $\begin{array}{c}\mathrm{H} 3 \\
\text { Reject }\end{array}$ \\
\hline $\begin{array}{l}\text { Knowledge has a positive influence } \\
\text { on driving discipline }\end{array}$ & - & 0.427 & $<0.0001$ & Significant & $\begin{array}{c}\mathrm{H} 4 \\
\text { Accept }\end{array}$ \\
\hline $\begin{array}{l}\text { Knowledge of each other has a } \\
\text { positive effect on vehicle } \\
\text { maintennance }\end{array}$ & - & 0.438 & $<0.0001$ & Significant & $\begin{array}{c}\mathrm{H} 5 \\
\text { Accent }\end{array}$ \\
\hline $\begin{array}{l}\text { Discipline attitude has a positive } \\
\text { influence on vehicle maintenance }\end{array}$ & - & 0.671 & $<0.0001$ & Significant & $\begin{array}{c}\mathrm{H} 6 \\
\text { Accept }\end{array}$ \\
\hline
\end{tabular}

\section{CONCLUSION}

Based on the result and discussion of data and analysis that has been done, the results can be summarized as follows:

1. This study links the latent variables of knowledge, discipline, care and traffic accidents.

2. Respondents in this study are majorly males with the percentage of $68.18 \%$ with age of respondents who range from 16 - 30 years are as many as $65.29 \%$, they who have a high school education makes up $52.89 \%$, they who has worked as a private employee makes up 53.72\% in 2017. $69.83 \%$ never had an accident and the ones who have experienced accident once makes up $22.31 \%$, they who had 5 - 10 years driving experience makes up 35.95\% and they who daily ride or drive for 2 - 3 hours as much as $37.6 \%$.

3. The variable of knowledge regarding traffic accident variable has a significant impact with the small standardize regression value of 0,154 . With that small value an increase is required.

4. Based on PERKAP 09 of 2012 Article 55; motorists are expected to have licenses, drive safely, observe and comply with all traffic regulations. When viewed, hypothesis (1) With the need for an increase in knowledge indicators in the form of; knowledge of regulatory content especially road mark and knowledge of regulation especially understanding of SIM which is still small will result in the lack of understanding the underlying theory and practice which represented by SIM (Indonesia Drive License). This creates bad attitude in traffic.

5. The disciplinary attitude variable to traffic accidents has significant impact with the small standardize regression value 0.315 . With such a small value, an increase is needed to achieve a value greater than 0.5 .

6. Based on Regulation no 22, 2009 on traffic, there is a section regarding traffic signs. The disciplinary attitude variable in essence has 5 indicator variables that break down into 24 statements. These 5 indicator variables include; orders, bans, warnings, suggestions, and instructions. If viewed hypothesis (2) need to increase the quality of command signs, warning, suggestions and instructions, especially the need for an increase in the quality of prohibition signs.

7. The vehicle maintenance variable does not significantly affect the small standardize regression value of 0.112 . With such a small value, an increase is needed to achieve a value greater than 0.5 .

8. Based on Regulation no 22 of 2009 and PERKAP 09 of 2012 Article 55, motorists are required to perform maintenance of their vehicle. As depicted by this hypothesis (3), respondents have understood the importance of maintenance of their motorcycle, such as checking the brakes, tires and exhaust. But there is still the need to increase awareness for checking the brakes, tires and exhaust before driving.

9. Based on PERKAP 09 of 2012 article 55, the riders need to understand and adapt during crowded driving situations. Knowledge variable and disciplinary attitude variable influence each other with value of covariance 0,427 . This can be seen as even when the driver has been driving on the road for quite a while, said person still perform a less than desirable attitude in traffic. This bad attitude can be caused by the knowledge of the riders themselves or the quality of the signs that are less helpful for good driving. If the rider already has good knowledge accompanied by the right quality of road signs, it will produce an ideal driving behavior.

10. Based on PERKAP 09 of 2012 article 55, the rider is expected to understand how to care for motorcycles. The variables of knowledge and treatment affect each other with the value of 0.438 covariance. This can be seen as the most of the respondent does not really understand how every and each of their motorcycle components work. They rather entrust the well-being of their vehicles to a verified garage.

11. Based on PERKAP 09 of 2012, which explained about caring for the vehicle. Variables regarding attitudes and treatment interacts with the value of 0.671 covariance. Respondents to this hypothesis (6) have been caring for their vehicles well. But there are still accidents caused by not doing small precautions like checking the tires and brake the vehicle before driving.

\section{REFERENCES}

[1]. Wesli. 2015. The Effcet of Motorized Knowledge on Motorcycle Riders Using Structural Equation Models (SEM). Teras Jurnal, 5(1), 43-50.

[2]. Lay, M. 2009. Handbook of Road Technology ( $4^{\text {th }}$ ed.). Taylor \& Francis e- Library, 2010.

[3]. Lulie, Y., \& Hatmoko, J.T. 2017. aggressive behavior causes the risk of accidents while driving. Interdisiciplinary Journal of Linguistics.

[4]. Marsaid, \& Ahsan. 2013. Traffic on Motorcycles in the POLRES Area. Journal of Nursing Science.

[5]. Goverment of Indonesia. 2009. According to Regulation No. 22. Goverment of Indonesia.

[6]. Ghozali, I. 2014. Model of Structural Equations. Badan Penerbit Universitas Diponegoro. 